\title{
Birds on the rim: a unique Lapita carinated vessel in its wider context
}

\author{
STUART BEDFORD and MATTHEW SPRIGGS
}

Keywords: Lapita, Teouma, modelled clay birds, pot burials.

\begin{abstract}
This paper describes a decorated carinated vessel excavated at the Teouma Lapita site, on the south coast of Efate, central Vanuatu. The vessel contained human bones and, following reconstruction, was found to have had four modelled birds on its rim. The incidence and dating of other burial pot assemblages is examined to place the find in a wider context within the Island Pacific.
\end{abstract}

The Teouma Lapita site on the south coast of Efate, Central Vanuatu was uncovered through construction work in 2003. It is one of the earliest Lapita sites yet identified in Vanuatu, dating to c. 3200-3000 BP, and excavations in 2004 revealed it to be the site of the earliest cemetery yet found in the Pacific (Bedford et al. 2004, 2006). The well-preserved nature of the site and the identification of distinct activity areas provide a rare opportunity to define in detail Lapita ceramic function and use. This is particularly the case in the cemetery area where an assortment of decorated Lapita vessels was associated with burial ritual.

Amongst the sherds recovered in the cemetery area of the site in 2004 was a modelled clay bird's head (Figure 1) very similar to one found in the SZ-8 Lapita site on Nendo Island in the Reef-Santa Cruz Group of the Southeast Solomons (Green 1979b:41). Dentate decoration can be seen running from behind the neck to underneath the eye and again above the eye. The eyes are represented by impressed circles and further dentate-stamping appeared to define a wing. Initial interpretations, based entirely on conjecture, were that it may have been a handle of some kind.

Investigations at Teouma in 2005 concentrated on the cemetery area alone, where some 100 square metres were excavated. The western edge of the 10 by 10 metre area was adjacent to the area where the bird's head had been uncovered. Clarification of the vessel form and function associated with the modelled head was soon revealed, although some radical reinterpretation of the handle hypothesis was required. Vessel association was initially hinted at by a number of rim sherds from a carinated vessel decorated with a dentate-stamped face motif. On the inside of the rim of three sherds were signs that something had

SB: Department of Archaeology and Natural History, Research School of Pacific and Asian Studies, Australian National University. stuart.bedford@anu.edu.au; MS: School of Archaeology and Anthropology, College of Arts and Social Sciences, Australian National University. matthew.spriggs@ anu.edu.au

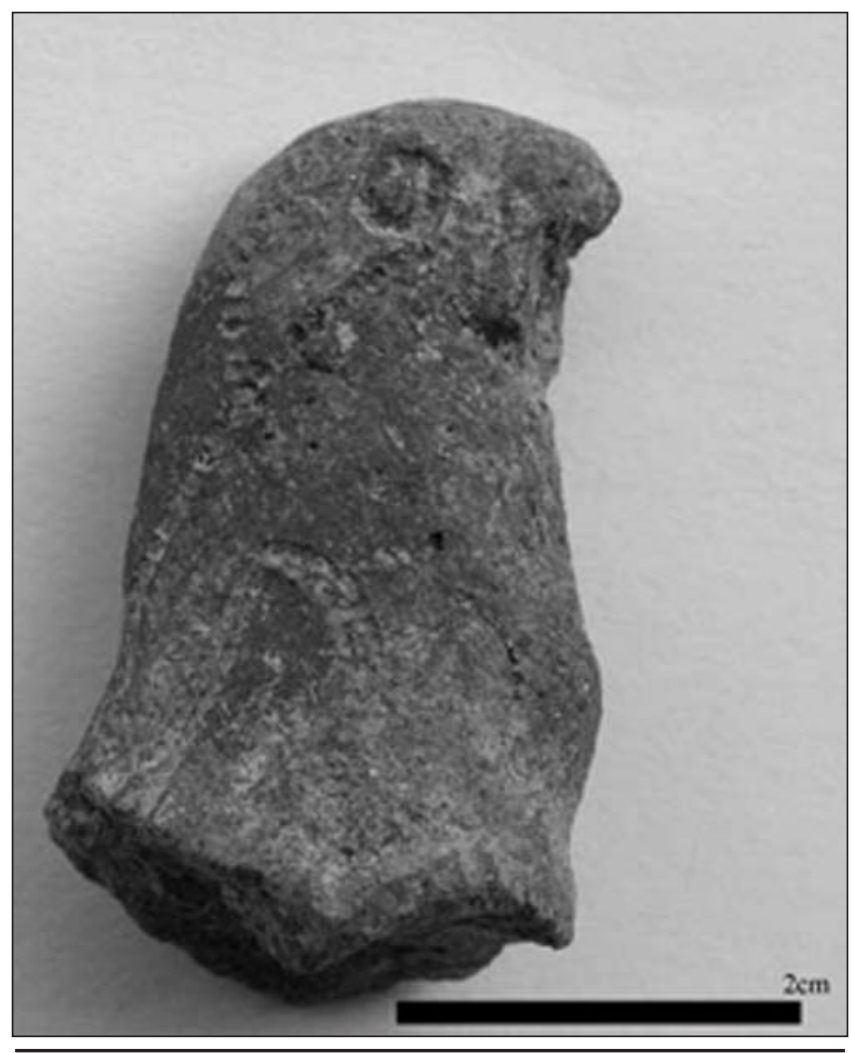

Figure 1. Modelled clay bird's head found at Teouma in 2004.

once been attached. This was confirmed when an almost whole bird was recovered, still attached to a rim sherd of the same vessel (Figure 2). The bird, it was revealed, was not remotely handle-like but rather positioned on the inside of the rim, fulfilling a symbolic and decorative role, with its head orientated towards the centre of the vessel (Figure 3). The three rim sherds with signs of once having had a bird attached, along with the more intact example, indicate a minimum of four birds on the rim.

The decorated sherds of this vessel were spread primarily over four square metres through different spits of the lowest cultural layer, although the largest concentrations were found in only two adjacent square metres. The basal part of the pot, largely still in situ, contained a collection of assorted human bone. The upper part of the pot had been broken and scattered in antiquity as a result of disturbance from later burials in the same area of the site. 


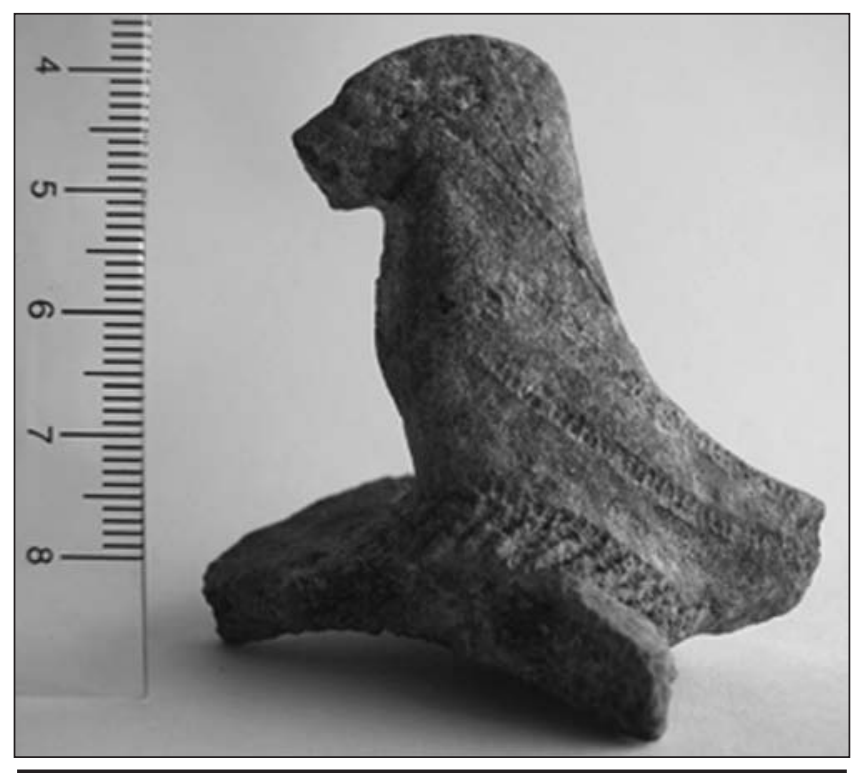

Figure 2. Modelled clay bird excavated in 2005 at Teouma. It is attached to the rim of a Lapita pot, facing into the vessel interior.
The recovery and reconstruction of this carinated pot with modelled birds on the rim adds a further very distinctive vessel form to the Lapita repertoire. However, the accumulated evidence of 50 years of research, along with the recovery of only a single example to date from the extensive excavations at Teouma, suggest that it will remain an extremely rare find. Its association with human remains both highlights and confirms the ceremonial nature of these decorated vessels generally and this form in particular. At the same time it indicates variation in burial practice and ritual at the site. This pot, along with another containing a skull (Bedford et al. 2006) from Teouma, provides the earliest evidence for pot or jar burials in the Pacific, a practice that has close parallels to burial ritual in Neolithic Island Southeast Asia including Taiwan (Bellwood 1997:220-1,240-1,272; Bintarti 2000; Chazine 2005; Harrisson 1974; Thiel 1986-7).

\section{Modelling}

Amongst the tens of thousands of decorated sherds that have been recovered through archaeological excavation, survey and avocational collection across the Lapita distribution there are very rare reports of modelled clay anthropo-

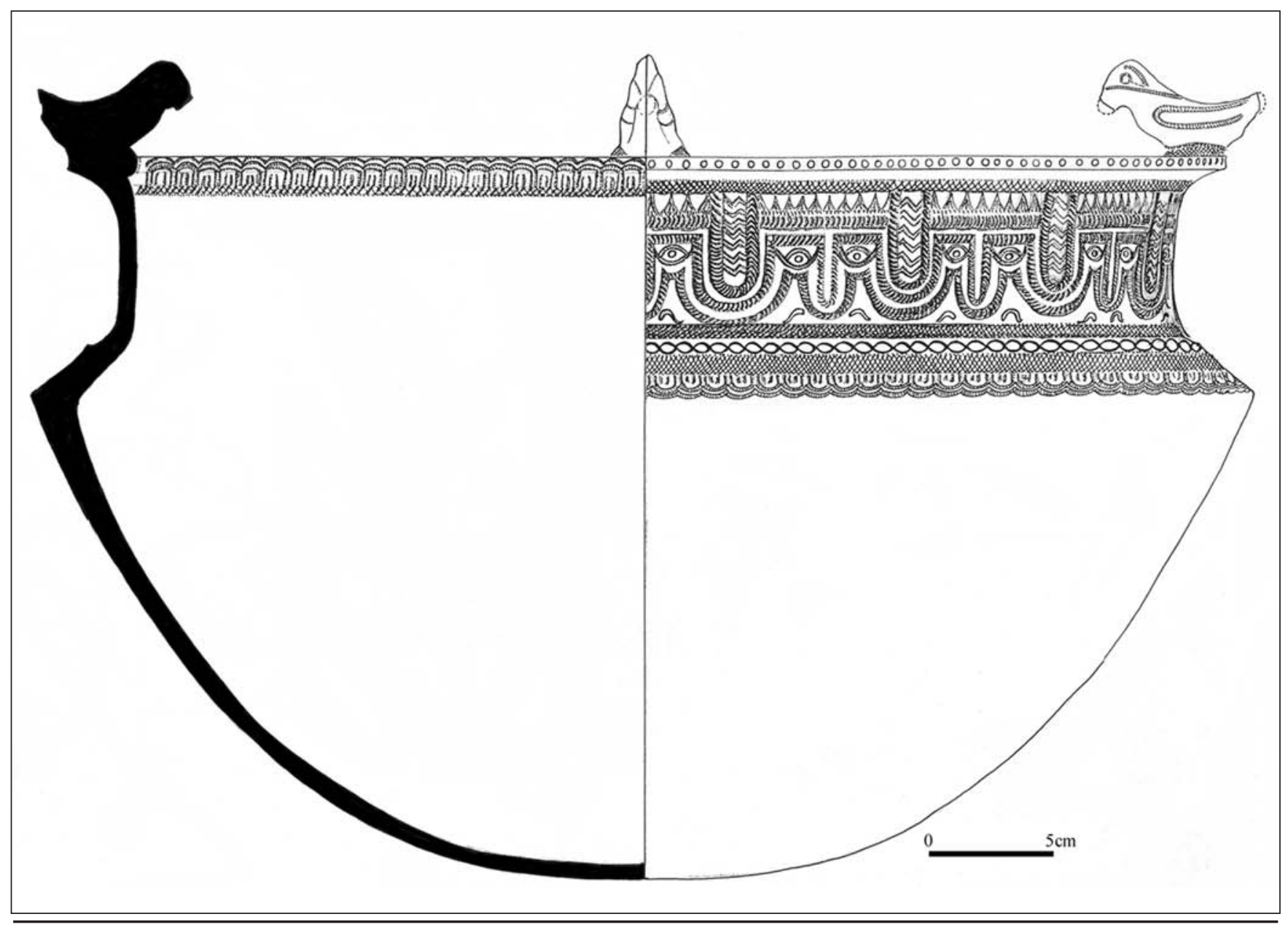

Figure 3. Reconstruction drawing of the Teouma Lapita pot with the modelled birds on the rim. Its basal portion was excavated in 2005 and contained human bones. 
morphic figures, faces and heads. Those that are decorated with dentate-stamping include a possible modelled human figure with decoration on the buttocks from site RL-6 in the Reef Islands of the southeast Solomons (Green 1979a:16), a clay head from Kamgot, on Babase Island, New Ireland (Summerhayes 1998:100) and three faces from Boduna Island, West New Britain (Torrence and White 2001). A further, somewhat ill-defined modelled object with dentatestamping, has been recovered from the Lau Islands in Fiji (O'Day et al. 2004). Another clay modelled head, without dentate decoration was found at NKM001 in New Caledonia (Frimigacci 1981; Sand 1996:122) and a moulded face, of somewhat uncertain provenance, has been found at Naigani in Fiji (Best 1981:11). A further modelled clay figure, of the avian variety, is the already-mentioned dentate-stamped bird head from SZ-8 in the Reef-Santa Cruz Group (Green 1979b:41).

Across the Pacific, archaeologically recovered clay modelled faces or figures of any form that post-date the Lapita period, are very rare. Some of the few examples identified to date are those from the Mangaasi site, also on Efate. They included a number of animal-like handles and an animal head (Garanger 1971:Figs 2 and 9) dating to around 2000 BP. Undated excavated assemblages containing pottery vessels with modelled human faces and heads and bird's heads are known from Selesmilage sites 3 and 4 in the Makbon area of the Bird's Head of western New Guinea, and turtle heads were found applied to the rim of an excavated vessel from Kumo Island, off Tobelo in northern Halmahera (Solheim 1991:14, 16-17). Pots with moulded human heads have been surface-collected from Jembekaki Fort on Batanta Island, off the western tip of the Bird's Head of New Guinea (Galis 1960; Galis and Kamma 1958). Some of the modelled heads from Jembekaki were placed on the rim looking into the pot.

For the recent past the picture is very different than the few examples above might suggest. A wide array of modelled faces on pot surfaces, modelled figures on the rims of pots and figurines have been recorded across much of New Guinea. They are vessel forms that are often, although not exclusively, used in a range of ceremonial activities (May and Tuckson 1982). Face pots have also been recorded in similarly late contexts in New Caledonia (Glaumont 1895:45; Sand 1995:146). While there is as yet little information on the antiquity of this tradition of modelling in New Guinea, the well-defined and lengthy ceramic sequences from such places as Buka, New Caledonia, Vanuatu and Fiji indicate that such modelling was restricted both in terms of production and chronology, features also noted for the Lapita period (see also Best 2002:72).

Modelled anthropomorphic heads or faces with dentatestamped designs have been argued as providing supportive evidence (Summerhayes 1998; Torrence and White 2001) of earlier assertions that associated tattooing with dentatestamping (Green 1979a; Green 1985; Kirch 1997). In terms of contributing to this debate the dentate-stamped birds are somewhat neutral. Others have suggested that modelled heads reinforce the idea that dentate-stamping is being com- bined with an earlier tradition of carved three-dimensional art, most of which has not survived due to utilisation of perishable materials (Torrence and White 2001:139). This may well be the case but the parallels found in Island Southeast Asia in vessel form, modelled clay figures and association with human remains suggest that the Teouma bird pot at least is connected with traditions that had their origins much further to the northwest (Cameron 2005; Dizon and Santiago 1996; Fox 1970:113-4; Lape 2000:162-3; van Stein-Callenfels 1952:90, Plate XIX; Tenazas 1974).

\section{Pot burial}

Burial in pots has been reported previously from Oceania but is comparatively rare, being found in New Guinea and its offshore islands, Bougainville, New Caledonia, and now in Vanuatu. As there has been no recent survey of this phenomenon in Oceania an Appendix is provided below in tabular form showing the distribution of the practice and, where such information is available, dates for its occurrence. A useful survey of pot burial for West Papua and Papua New Guinea was given by Guise (1985), based largely on the PNG National Museum site files. This included two accompanying maps but was largely without other references. This information was drawn upon, along with further references that were apparently not available to Guise at the time or which are of more recent date. Ollier and Holdsworth (1977) summarised cave burial practices from Milne Bay Province, PNG, with many useful references.

From the references examined it is not always clear whether burial in pots or burial with accompanying pots as grave goods is being referred to. This latter practice is also found at Teouma, where a large upturned carinated vessel with dentate-stamped decoration was seemingly in association either with a pot containing a human skull with an upturned flat-bottomed dish on top of it, and/or with an adjacent inhumation (see photographs in Bedford et al. 2006). For this reason we have included references to both practices in the Appendix. Pots as grave goods are attested from the New Guinea region, possibly Bougainville, Vanuatu, Fiji, the Marianas Islands and Palau.

Whether in fact the upturned flat-bottomed dish at Teouma was merely sealing the burial urn, or whether it represents the practice of placing a pot on top of the skull is unclear. This latter practice, as can be seen from the several examples given in the Appendix, is surprisingly widespread in the Island Pacific. It has been recorded for New Guinea, Vanuatu, New Caledonia, Fiji and possibly Guam. The practice of placing a pot over the skull attracted the notice of Riesenfeld (1950:329-330), who considered it typical of his "stone-using" or "megalithic" migrants, and the practice was supposedly often combined with burial in a sitting position. It is notable that it is also a practice recorded for Taiwan in the Neolithic Beinan Culture, where placing "a large half pot over the face or head of the dead person" was common practice at the Peinan burial site where pottery was 
also found as grave goods with primary inhumations in slate coffins (Lien 1990: 345, 346). Placing a pot over the skull is also found later in Taiwan in the Iron Age Fanziyuan Culture. Extended and prone burials are found in that culture and "the skull is usually covered by a pot" (Tsang 2000:155).

The Appendix does not claim to be exhaustive but represents occurrences from all the areas where we believe that pot burial was practiced in the Island Pacific. In compiling the Appendix it was necessary to be somewhat selective in what references were accepted as relevant. For instance, Riesenfeld (1950:639) quotes Schlaginhaufen (1910:39) as suggesting that some of the jars produced in the Sepik area of New Guinea might have been used for burial, but the reference is vague and not supported by other authors, and so is omitted from the Appendix. Also omitted, but worth noting, is the presence of burial urns in stone on Choiseul Island in the Western Solomons (Bernatzik 1935:73-5, fig. 43). As far as could be ascertained this is a unique occurrence in the Island Pacific, although not uncommon in prehistoric Island and Mainland Southeast Asia, where stone sarcophagi are also found in Metal Age contexts of the last 2000 years (Bellwood 1997: 290, 293, 306; Sayavongkhamdy and Bellwood 2000).

The Appendix shows that pot burial is by no means found in all areas where pottery was used prehistorically, and tends in many cases to be a phenomenon of the last millennium, particularly in the New Guinea area. In New Caledonia it is a practice that is primarily found between 2000 and 1000 BP. If we turn to burial where pots have been placed on top of the head, there is a New Caledonian example from the immediately post-Lapita period, dating to about $2700 \mathrm{BP}$. The only Fijian example of this practice dates to about 1700-1500 BP and comes from Sigatoka on Viti Levu. Pots as grave goods as opposed to burial in pots have been reported ethnographically from various places. Archaeologically it is sometimes difficult to establish a convincing primary association between pottery and burials in a site. Early first millennium BC Palau would seem at first glance to be the nearest in age to the Teouma case for pottery as grave goods, but there are serious problems with radiocarbon dates from that archipelago, particularly those involving the dating of pottery temper (Anderson et al. 2005). This means that the examples from Palau could potentially be much younger than their apparent age. All of these practices are associated with Austronesian-speaking areas, or areas such as Koiari in southern Papua which were in close association with and adjacent to Austronesianspeaking groups.

\section{Conclusion}

The study of the Teouma pots and a survey of the comparative literature reveal that Teouma presents the earliest known Pacific examples of pot burial, and the earliest example of pottery as grave goods yet found in the region. If the dentate-decorated flat-bottomed dish placed over the skull contained in a second burial pot is taken as a representative of the mortuary practice of placing a pot over the skull, rather than simply as a convenient 'lid' for the burial vessel, then this practice too finds its earliest Pacific representative in Teouma ${ }^{1}$.

Pot burial and pottery as grave goods are widespread in Island Southeast Asia in Neolithic contexts that might be seen as at least in part ancestral to Lapita, and placement of a pot over the skull in mortuary ritual is known from Neolithic and later contexts in Taiwan. One possibility is that such practices were continually reinvented, as might be perceived to be the explanation for pot burial in the Massim area of Milne Bay Province, PNG during the last 1000 years and its practice in the preceding millennium in distant New Caledonia.

An alternative would be to see them as an ancestral Island Southeast Asian Neolithic burial complex that spread to the Pacific with Lapita and represents a continuous tradition in some areas until European contact. Golson (1972:581-586) saw the Massim examples as representing a later period of contact with Island Southeast Asia in the more recent past. As we clearly lack the evidence of continuous mortuary ritual sequences over much of the Island Pacific in the areas covered by the Appendix, an open mind on the question until further evidence is adduced would seem to be perhaps the most prudent stance to take.

\section{Acknowledgements}

Investigations at Teouma are being undertaken as a joint project of the Australian National University and the Vanuatu Cultural Centre. Fidel Yoringmal drew Figure 3. Funding has been provided by the Australian Research Council (DP 0556874), the Pacific Biological Foundation, the Royal Society of New Zealand (Marsden Faststart), Snowy Mountains Electricity Commission Foundation, the Department of Archaeology and Natural History and School of Archaeology and Anthropology, Australian National University and Mr Brian Powell. We would like to thank Pam Swadling for providing an unpublished translation of Galis' 1964 publication, and Simon Bickler, Geoff Irwin and Vincent Kewibu for other helpful assistance. Useful comments were received on an earlier draft of the paper from Hallie Buckley and Frédérique Valentin. Editorial comments from Peter White and an anonymous referee have also been very helpful.

\section{References}

Anderson, A., J. Chappell, G. Clark and S. Phear 2005. Comparative radiocarbon dating of lignite, pottery, and charcoal samples from Babeldaob Island, Republic of Palau. Radiocarbon 47(1): 1-9.

1. A skull with large potsherds placed over it was found during the 2006 field season at Teouma, as was a further pot with human bones placed within it. 
Bedford, S., A. Hoffman, M. Kaltal, R. Regenvanu and R. Shing. 2004. Dentate-stamped Lapita reappears on Efate, Central Vanuatu: a four decade-long drought is broken. Archaeology in New Zealand 47(1): 39-49.

Bedford, S., M. Spriggs and R. Regenvanu. 2006. The Teouma Lapita site and the early human settlement of the Pacific Islands. Antiquity 80: 812-28.

Bellwood, P. 1997. Prehistory of the Indo-Malaysian Archipelago. Second edition. Honolulu: University of Hawaii Press.

Bernatzik, H.A. 1935. South Seas. New York: Henry Holt.

Best, S. 1981. Excavations at Site VL 21/5 Naigani Island, Fiji, a preliminary report. Department of Anthropology, University of Auckland.

Best, S. 2002. Lapita: A View from the East. New Zealand Archaeological Association Monograph 24.

Bintarti, D.D. 2000. More on urn burials in Indonesia. Bulletin of the Indo-Pacific Prehistory Association 19: 73-76.

Cameron, J. 2005. Pottery figurines in the archaeological record of South China, Southeast Asia and the Pacific. Paper presented at the Oceanic Explorations Conference, August 2005, Tonga.

Chazine, J.-M. 2005. Rock art, burials and habitations: caves in East Kalimantan. Asian Perspectives 44(1): 219-229.

Dizon, E. and R. Santiago. 1996. Faces from Maitum. The archaeological excavation of Ayub Cave. Manila: The National Museum of the Philippines.

Fox, R. 1970. The Tabon Caves. Archaeological explorations and excavations on Palawan Island, Philippines. Monograph of the National Museum 1. Manila: National Museum of the Philippines.

Frimigacci, D. 1981. Fouilles de Sauvetage en NouvelleCalédonie. Nouméa: ORSTOM.

Galis, K.W. 1960. Het Fort te Jembekaki: Addendum. NieuwGuinea Studien 4: 52-4.

Galis, K.W. and F.C. Kamma 1958. Het Fort te Jembekaki. Nieuw-Guinea Studien 2: 206-222.

Garanger, J. 1971. Incised and applied relief pottery, its chronology and development in southeastern Melanesia, and the extra areal comparisons. In R. Green and M. Kelly (eds.) Studies in Oceanic Culture History, Volume 2, pp. 53-66. Honolulu: Pacific Anthropological Records 12.

Glaumont, M. 1895. De l'art du potier de terre. Chez les NéoCalédoniens. L'Anthropologie 16: 40-52.

Golson, J. 1972. Both sides of the Wallace Line: New Guinea, Australia, Island Melanesia and Asian prehistory. In N. Barnard (ed.) Early Chinese Art and its Possible Influence in the Pacific Basin, Vol. 3, pp. 533-595. New York: Intercultural Arts Press.

Green, R.C. 1979a. Early Lapita art from Polynesia and Island Melanesia: Continuities in Ceramic, Barkcloth and Tattoo decorations. In S.M. Mead (ed.) Exploring the Visual Art of Oceania, pp. 13-31. Honolulu: University of Hawaii Press.

Green, R.C. 1979b. Lapita. In J.D. Jennings (ed.) The Prehistory of Polynesia, pp. 27-60. Cambridge, Mass.: Harvard University Press.

Green, R.C. 1985. Comment on The Lapita Cultural Complex by M. Spriggs. Journal of Pacific History 20: 220-224.
Guise, A. 1985. Oral Tradition and Archaeological Sites in the Eastern Central Province. Records of the PNG National Museum 9. Port Moresby: IPNGS.

Harrisson, T. 1974. Early "jar burials" in Borneo and elsewhere. Asian Perspectives 17(2): 141-144.

Kirch, P.V. 1997. The Lapita Peoples. Ancestors of the Oceanic World. Oxford: Blackwell.

Lape, P.V. 2000. Contact and Conflict in the Banda Islands, Eastern Indonesia, 11th-17th Centuries. Unpublished PhD thesis, Brown University, Rhode Island.

Lien, C.-M. 1990. Neolithic archaeology of Taiwan and the Peinan Excavations. Bulletin of the Indo-Pacific Prehistory Association 11: 339-352.

May, P. and M. Tuckson 1982. The Traditional Pottery of New Guinea. Sydney: Bay Books.

O'Day, S.J., P. O'Day and D. Steadman 2004. Defining the Lau Context: Recent findings on Nayau, Lau Islands, Fiji. New Zealand Journal of Archaeology 25(2003): 31-56.

Ollier, C.D. and D.K. Holdsworth 1977. Cave burials of Eastern Papua. Studies in Speleology 3(2): 50-65.

Riesenfeld, A. 1950. The Megalithic Culture of Melanesia. Leiden: E.J. Brill.

Sand, C. 1995. "Le Temps d'Avant" la préhistoire de la Nouvelle-Calédonie. Paris: L'Harmattan.

Sand, C. 1996. Le début du peuplement austronésian de la Nouvelle-Calédonie: données archéologiques récentes. Département Archéologie du Service des Musées et du Patrimonie. Les Cahiers de l'Archéologie en NouvelleCalédonie 6.

Sayavongkhamdy, T. and P. Bellwood 2000. Recent archaeological research in Laos. Bulletin of the Indo-Pacific Prehistory Association 19: 101-108.

Schlaginhaufen, O. 1910. Eine Ethnographische Sammlung vom Kaiserin-Augusta-Fluss in Neuguinea. Leipzig.

Solheim, W.G. II 1991 Provisional Final Report to LIPI on Archaeological Research Program in Eastern Indonesia. Manuscript report.

van Stein-Callenfels, P.V. 1952. Prehistoric Sites on the Karama River, West Torajaland, Central Celebes. Journal of East Asiatic Studies 1: 82-97.

Summerhayes, G. 1998. The Face of Lapita. Archaeology in Oceania 33: 100.

Tenazas, R.C.P. 1974. A progress report on the Magushot excavations in Bacong, Negros Oriental, Summer 1974. Philippine Quarterly of Culture and Society 2: 133-155.

Thiel, B. 1986-7 [pub. 1990]. Excavations at Arku Cave, northeast Luzon, Philippines. Asian Perspectives 27(2): 229-264.

Torrence R. and J.P White. 2001. Tattooed faces from Boduna Island, Papua New Guinea. In G.A. Clark, A. Anderson and T. Sorovi-Vunidilo (eds.) The Archaeology of Lapita Dispersal in Oceania: Papers from the Fourth Lapita Conference, June 2000, Canberra, Australia, pp. 135-140. Terra Australis 17.

Tsang, C.W. 2000. Recent advances in the Iron Age archaeology of Taiwan. Bulletin of the Indo-Pacific Prehistory Association 20: 153-158. 
Appendix: The associations of burials with pottery in the Pacific Islands

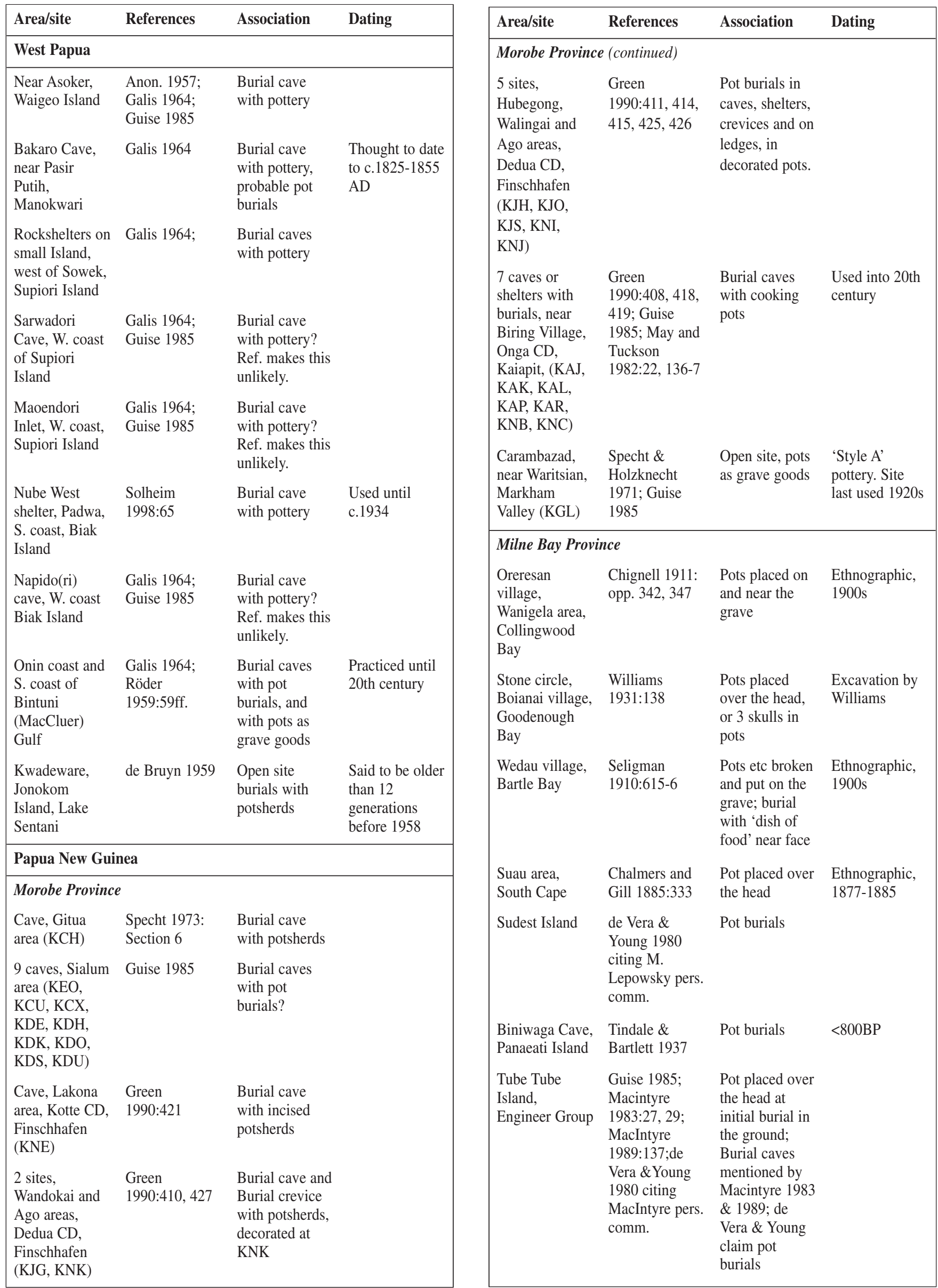




\begin{tabular}{|c|c|c|c|}
\hline Area/site & References & Association & Dating \\
\hline \multicolumn{4}{|c|}{ Milne Bay Province (continued) } \\
\hline $\begin{array}{l}5 \text { caves, } \\
\text { Kiriwina } \\
\text { (Kilivila) } \\
\text { Island, } \\
\text { Trobriands } \\
\text { (BDZ, BQA, } \\
\text { BQB, BEG, } \\
\text { BIM) }\end{array}$ & $\begin{array}{l}\text { Austen 1939; } \\
\text { Egloff 1979: } \\
\text { 107; Guise } \\
\text { 1985; Ollier \& } \\
\text { Holdsworth } \\
\text { 1968; Williams } \\
\text { 1931:140 citing } \\
\text { Rentoul pers. } \\
\text { comm. (BQA). }\end{array}$ & Pot burials & $<800 \mathrm{BP}$ \\
\hline $\begin{array}{l}\text { Neguya cave, } \\
\text { Kiriwina Island }\end{array}$ & $\begin{array}{l}\text { Ollier \& } \\
\text { Holdsworth } \\
\text { 1971a }\end{array}$ & $\begin{array}{l}\text { Prob. Pot } \\
\text { burials }\end{array}$ & $<800 \mathrm{BP}$ \\
\hline $\begin{array}{l}\text { Obuwaga cave, } \\
\text { near Labai, } \\
\text { Kiriwina Island }\end{array}$ & $\begin{array}{l}\text { Burenhult } \\
\text { 2002: } \\
\text { 9,34,109,127; } \\
\text { Egloff 1973: } \\
\text { plate IVb; } \\
\text { Lauer 1971:206 }\end{array}$ & Pot burials & $<800 \mathrm{BP}$ \\
\hline $\begin{array}{l}\text { Otuyam } \\
\text { megaliths, } \\
\text { Kiriwina Island }\end{array}$ & Austen 1939 & $\begin{array}{l}\text { Burials \& } \\
\text { pottery }\end{array}$ & $\begin{array}{l}\text { Found in } \\
\text { excavation }\end{array}$ \\
\hline $\begin{array}{l}\text { Old village site, } \\
\text { Odubekoya, } \\
\text { Kiriwina Island }\end{array}$ & $\begin{array}{l}\text { Burenhult } \\
\text { 2002: } \\
\text { 10,40,74,127, } \\
\text { 133; Winter } \\
2003\end{array}$ & $\begin{array}{l}\text { Burials \& } \\
\text { pottery in } \\
\text { association }\end{array}$ & $\begin{array}{l}{ }^{14} \mathrm{C} \text { dates on } \\
\text { human bone of } \\
1100+/-70 \mathrm{BP} \\
\text { (grave 2), and } \\
755+/-70 \mathrm{BP} \\
\text { (grave 3) }\end{array}$ \\
\hline $\begin{array}{l}3 \text { caves, Kitava } \\
\text { Island, } \\
\text { Trobriands } \\
\text { (BCK, BCL, } \\
\text { BCN); also } \\
\text { probably Kausi } \\
\text { cave }\end{array}$ & $\begin{array}{l}\text { Guise 1985; } \\
\text { Ollier \& } \\
\text { Holdsworth } \\
1970\end{array}$ & Pot burials & $<800 \mathrm{BP}$ \\
\hline $\begin{array}{l}5 \text { caves: } \\
\text { Yavakuta, } \\
\text { Olokwaleku, } \\
\text { Bokaulawola, } \\
\text { Kousuma } \\
\text { (Ollier et al), } \\
\text { Dabadaba } \\
\text { (Gerrits), } \\
\text { Kitava Island }\end{array}$ & $\begin{array}{l}\text { Gerrits 1974; } \\
\text { Ollier et al. } \\
1971\end{array}$ & $\begin{array}{l}\text { Burials and } \\
\text { pottery, } \\
\text { probably pot } \\
\text { burials }\end{array}$ & $<800 \mathrm{BP}$ \\
\hline $\begin{array}{l}\text { Kadalalai } \\
\text { megaliths, } \\
\text { Kitava Island }\end{array}$ & Austen 1939 & $\begin{array}{l}\text { Burials and } \\
\text { pottery }\end{array}$ & $\begin{array}{l}\text { Found in } \\
\text { excavation }\end{array}$ \\
\hline $\begin{array}{l}4 \text { caves, Vakuta } \\
\text { Island, } \\
\text { Trobriands } \\
\text { (BDB, BDC, } \\
\text { BDE, BDF) }\end{array}$ & $\begin{array}{l}\text { Austen 1939; } \\
\text { Guise 1985; } \\
\text { Ollier \& } \\
\text { Holdsworth } \\
1969\end{array}$ & Pot burials & $<800 \mathrm{BP}$ \\
\hline $\begin{array}{l}\text { Wagaru } \\
\text { megaliths, } \\
\text { Vakuta Island }\end{array}$ & $\begin{array}{l}\text { Ollier et al. } \\
1970\end{array}$ & $\begin{array}{l}\text { Probable burial } \\
\text { and pottery } \\
\text { under one of } \\
\text { the stones }\end{array}$ & \\
\hline $\begin{array}{l}3 \text { caves etc, } \\
\text { Kaileuna Island, } \\
\text { Trobriands } \\
\text { (BQC, BQD, } \\
\text { BQE) }\end{array}$ & $\begin{array}{l}\text { Guise 1985; } \\
\text { Ollier \& } \\
\text { Holdsworth } \\
\text { 1971b }\end{array}$ & Pot burials & $<800 \mathrm{BP}$ \\
\hline
\end{tabular}

\begin{tabular}{|c|c|c|c|}
\hline Area/site & References & Association & Dating \\
\hline \multicolumn{4}{|c|}{ Milne Bay Province (continued) } \\
\hline $\begin{array}{l}\text { Rockshelter, } \\
\text { Mapas Island, } \\
\text { in Suloga } \\
\text { Harbour, } \\
\text { Woodlark Is. }\end{array}$ & Lyons 1922 & Pot burials & $<800 \mathrm{BP}$ \\
\hline $\begin{array}{l}\text { many caves etc, } \\
\text { Woodlark } \\
\text { Island (incl. } \\
\text { BJN, BMV, } \\
\text { BJM, BKG, } \\
\text { BMY, BNA, } \\
\text { BKH, BJG) }\end{array}$ & $\begin{array}{l}\text { Bickler 1998, } \\
\text { 1999; Bickler } \\
\text { \& Turner 2002: } \\
\text { 15; Guise 1985; } \\
\text { Ollier \& Pain } \\
\text { 1978a; Selig- } \\
\text { man 1910:731; } \\
\text { Seligman \& } \\
\text { Strong } \\
\text { 1906:348 }\end{array}$ & Pot burials & $\begin{array}{l}<800 \mathrm{BP} \\
\text { (Bickler has } \\
\text { dates 787- } \\
\text { 650BP, 697- } \\
548 \mathrm{BP}, 620- \\
\text { 320BP, 636- } \\
\text { 503BP on bone } \\
\text { from pot } \\
\text { burials) }\end{array}$ \\
\hline 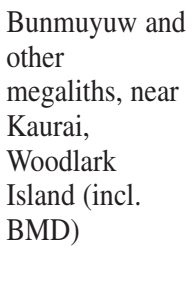 & $\begin{array}{l}\text { Bickler 2006; } \\
\text { Bickler \& } \\
\text { Ivuyo 2002; } \\
\text { Forth 1965; } \\
\text { Ollier \& Pain } \\
\text { 1978b }\end{array}$ & $\begin{array}{l}\text { Pot burials later } \\
\text { than megaliths }\end{array}$ & $\begin{array}{l}<800 \mathrm{BP} \\
\text { (Bickler has } \\
\text { dates } 740- \\
540 \mathrm{BP}(780+/- \\
55), 670-510 \mathrm{BP} \\
(685+/-55) \text { on } \\
\text { bone from pot } \\
\text { burials) }\end{array}$ \\
\hline $\begin{array}{l}\text { Cave, } \\
\text { Nasikwabw } \\
\text { (Alcester) } \\
\text { Island, S. of } \\
\text { Woodlark } \\
\text { (BJN) }\end{array}$ & Guise 1985 & $\begin{array}{l}\text { Burial caves } \\
\text { with pot } \\
\text { burials? }\end{array}$ & \\
\hline $\begin{array}{l}\text { Rockshelter, } \\
\text { Unavek Island, } \\
\text { Budibudi } \\
\text { (Laughlan) } \\
\text { Islands, E. of } \\
\text { Woodlark }\end{array}$ & Bickler 1999 & Pot burials & $<800 \mathrm{BP}$ \\
\hline $\begin{array}{l}\text { Cliff complex, } \\
\text { Nuamata } \\
\text { Island, near } \\
\text { Goodenough } \\
\text { Island (BJJ) }\end{array}$ & $\begin{array}{l}\text { Egloff 1972, } \\
\text { 1979:107-8; } \\
\text { Guise 1985 }\end{array}$ & Pot burials & $<800 \mathrm{BP}$ \\
\hline $\begin{array}{l}5 \text { caves etc, } \\
\text { Goodenough Is. } \\
\text { (BMB, BMC, } \\
\text { BQF, BQG, } \\
\text { and more) }\end{array}$ & $\begin{array}{l}\text { Guise 1985; de } \\
\text { Vera \& Young } \\
1980\end{array}$ & Pot burials & $<800 \mathrm{BP}$ \\
\hline $\begin{array}{l}\text { Normanby } \\
\text { Island, near } \\
\text { Goodenough } \\
\text { Island }\end{array}$ & Guy 1937:26 & $\begin{array}{l}\text { Pot placed over } \\
\text { the head of } \\
\text { corpse }\end{array}$ & $\begin{array}{l}\text { Ethnographic, } \\
\text { 1930s }\end{array}$ \\
\hline Dobu Island & $\begin{array}{l}\text { Fortune } \\
\text { 1932:180 }\end{array}$ & $\begin{array}{l}\text { Pot placed over } \\
\text { the head of the } \\
\text { corpse for } \\
\text { about a week } \\
\text { prior to burial }\end{array}$ & $\begin{array}{l}\text { Ethnographic, } \\
\text { 1920s }\end{array}$ \\
\hline $\begin{array}{l}8 \text { caves etc, } \\
\text { Misima Island } \\
\text { (BNL, BNN, } \\
\text { BNO, BNP, } \\
\text { BNH, BNI, } \\
\text { BJD BPA) }\end{array}$ & $\begin{array}{l}\text { Guise 1985; } \\
\text { Pain \& Ollier } \\
1978\end{array}$ & Pot burials & $<800 \mathrm{BP}$ \\
\hline
\end{tabular}




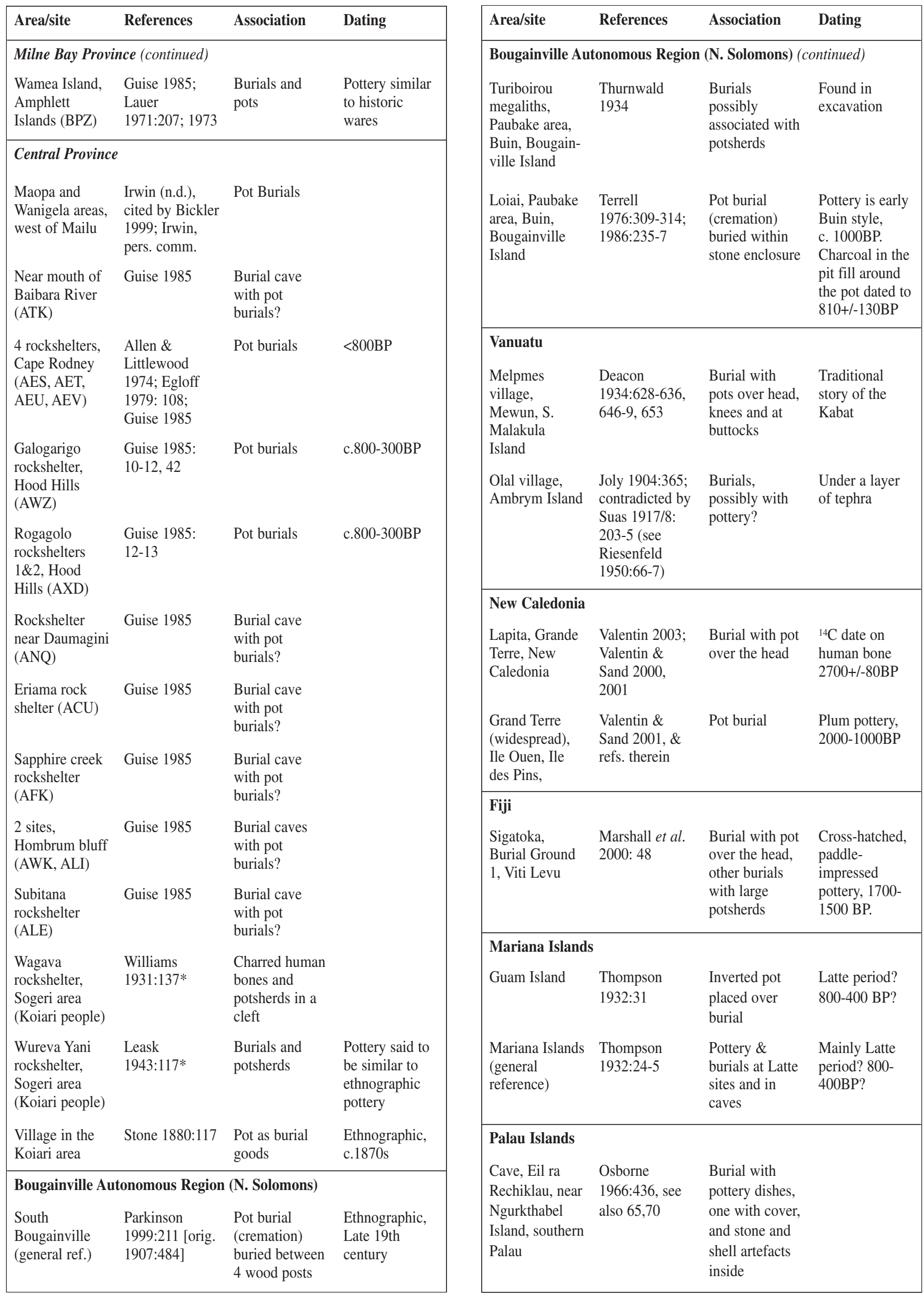




\begin{tabular}{|c|c|c|c|}
\hline Area/site & References & Association & Dating \\
\hline \multicolumn{4}{|c|}{ Palau Islands (continued) } \\
\hline $\begin{array}{l}\text { Sengall Ridge } \\
\text { cave, Koror } \\
\text { Island }\end{array}$ & $\begin{array}{l}\text { Beardsley \& } \\
\text { Basileus } 2002\end{array}$ & $\begin{array}{l}\text { Pottery } \\
\text { dishes/bowls } \\
\text { with burials in } \\
\text { cave }\end{array}$ & $\begin{array}{l}{ }^{14} \mathrm{C} \text { date of } \\
2630+/-60 \mathrm{BP} \\
\text { on pottery } \\
\text { inclusions is } \\
\text { possibly } \\
\text { unreliable (See } \\
\text { Anderson et al. } \\
2005 \text { ) }\end{array}$ \\
\hline $\begin{array}{l}\text { Ngermereues } \\
\text { Ridge caves, } \\
\text { Koror Island }\end{array}$ & $\begin{array}{l}\text { Welch } \\
\text { 2001:181, } \\
\text { citing Rieth \& } \\
\text { Liston } 2001\end{array}$ & $\begin{array}{l}\text { Burials and } \\
\text { pottery in two } \\
\text { caves }\end{array}$ & $\begin{array}{l}{ }^{14} \mathrm{C} \text { dates on } \\
\text { human bone: } \\
2480+/-40 \mathrm{BP} \text {, } \\
1720+/-40 \mathrm{BP} \text {, } \\
1350+/-40 \mathrm{BP}\end{array}$ \\
\hline
\end{tabular}

* These sites are possibly the same as some sites in the four columns above them.

\section{References for the Appendix}

Allen, J. and H. Littlewood 1974. Funerary cave pottery from the Cape Rodney area, Central Papua. Records of the P.N.G. Museum 4:1-20. Port Moresby: IPNGS.

Anderson, A., J. Chappell, G. Clark and S. Phear 2005. Comparative radiocarbon dating of lignite, pottery, and charcoal samples from Babeldaob Island, Republic of Palau. Radiocarbon 47(1):1-9.

Anonymous 1957. Interessante vondst op het Eiland Waigeo. Nieuw-Guinea Studien 1:59-60.

Austen, L. 1939. Megalithic structures in the Trobriand Islands. Oceania 10(1):30-53.

Beardsley, F. and U. Basileus 2002. Sengall Ridge, Belau: burials, spirit walks, and painted pottery. Bulletin of the Indo-Pacific Prehistory Association 22:147-151.

Bickler, S. 1998. Eating Stone and Dying: archaeological survey on Woodlark Island, Milne Bay Province, Papua New Guinea. Unpublished $\mathrm{PhD}$ thesis, University of Virginia.

Bickler, S. 1999. Secondary burial practices in the northern Kula Ring. In M. Boyd, J.C. Erwin and M. Hendrickson (eds) The Entangled Past: Integrating history and archaeology, pp. 98-107. Proceedings of the 30th Annual Chacmool Conference. Calgary: Archaeological Association of the University of Calgary.

Bickler, S. 2006. Prehistoric stone monuments in the northern region of the Kula Ring. Antiquity 80:38-51.

Bickler, S. and B. Ivuyo 2002. Megaliths of Muyuw (Woodlark Island), Milne Bay Province, PNG. Archaeology in Oceania 37:22-36.

Bickler, S. and M. Turner 2002. Food to stone: investigations at the Suloga adze manufacturing sites, Woodlark Island, Papua New Guinea. Journal of the Polynesian Society 111(1):11-43

De Bruyn, J.V. 1959. New archaeological finds at Lake Sentani. Nieuw-Guinea Studien 3: 1-8.

Burenhult, G. (ed.) 2002. The Archaeology of the Trobriand Islands, Milne Bay Province, Papua New Guinea, Excavation Season 1999. British Archaeological Reports International Series 1080. Oxford: BAR.

Chalmers, J. and W.W. Gill 1885. Work and Adventure in New Guinea. London: Religious Tract Society.

Chignell, A.K. 1911. An Outpost in Papua. London: Smith, Elder \& Co.
Deacon, A.B. 1934. Malekula: a vanishing people in the New Hebrides. London: Routledge.

Egloff, B.J. 1972. The sepulchral pottery of Nuamata Island, Papua. Archaeology and Physical Anthropology in Oceania 7(2):145-163.

Egloff, B.J. 1973 Archaeological research in the Collingwood Bay area of Papua. Asian Perspectives 14:60-64.

Egloff, B.J. 1979. Recent Prehistory in Southeast Papua. Terra Australis 4. Canberra: Department of Prehistory, RSPacS, ANU.

Forth, R.L. 1965. Stone arrangements on Woodlark Island. Mankind 6(6):257-263.

Fortune, R. F. 1932. Sorcerers of Dobu. London: Routledge.

Galis, K.W. 1964. Recent oudheidkundig Nieus uit Westelijk Nieuw-Guinea. Bijdragen tot de Taal-, Land, en Volkenkunde 120(2):245-274.

Gerrits, G.J.M. 1974. Burial-Canoes and Canoe-burials in the Trobriand and Marshall Bennett Islands (Melanesia). Anthropos 69:224-231.

Green, M.K. 1990. Prehistoric Cranial Variation in Papua New Guinea. Unpublished $\mathrm{PhD}$ thesis, Australian National University, Canberra.

Guise, A. 1985. Oral Tradition and Archaeological Sites in the Eastern Central Province. Records of the PNG National Museum 9. Port Moresby: IPNGS.

Guy, A.W. 1937. People of the D'Entrecasteaux Group. Walkabout, July 1st, 24-27.

Irwin, G. n.d. [1971]. Field notes from survey on the southeast coast of Papua. Unpublished manuscript, Department of Anthropology, University of Auckland.

Joly, P.R. 1904. Notes sure les Nouvelles-Hébrides. Bulletin et Memoire de la Société d'Anthropologie de Paris 5: 356-369.

Lauer, P. K. 1971. Changing patterns of pottery trade to the Trobriand Islands. World Archaeology 3(2):197-209.

Leask, M.F. 143. Rock engravings and paintings of the Sogeri District of Papua. Mankind 3(4):116-120.

Lyons, A.P. 1922. Sepulchral pottery of Murua, Papua. Man 22 (Article 93):164-165.

Macintyre, M. 1983. Warfare and the changing context of 'Kune' on Tubetube. Journal of Pacific History 18:11-34.

Macintyre, M. 1989. The triumph of the Susu: mortuary exchanges on Tubetube. In F.H. Damon and R. Wagner (eds) Death Rituals and Life in the Societies of the Kula Ring, pp. 133-152. De Kalb: Northern Illinois University Press

Marshall, Y., A. Crosby, S. Matararaba and S. Wood. 2000. Sigatoka: The shifting sands of Fijian prehistory. University of Southampton Department of Archaeology Monograph 1. Oxford: Oxbow Books.

May, P. and M. Tuckson 1982. The Traditional Pottery of New Guinea. Sydney: Bay Books.

Ollier, C.D. and D.K. Holdsworth 1968. Caves of Kiriwina, Trobriand Islands, Papua. Helictite 6(4):63-72.

Ollier, C.D. and D.K. Holdsworth 1969. Caves of Vakuta, Trobriand Islands, Papua. Helictite 7(3):50-61.

Ollier, C.D. and D.K. Holdsworth 1970. Some caves of Kitava, Trobriand Islands, Papua. Helictite 8(2):29-38.

Ollier, C.D. and D.K. Holdsworth 1971a. Further caves of Kiriwina, Trobriand Islands, Papua. Helictite 9(4):77-84.

Ollier, C.D. and D.K. Holdsworth 1971b. Caves of Kaileuna and Tuma, Trobriand Islands. Helictite 9(2):29-48.

Ollier, C.D., D.K. Holdsworth and G. Heers 1970. Megaliths at Wagaru, Vakuta, Trobriand Islands. Archaeology and Physical Anthropology in Oceania 5:24-26.

Ollier, C.D., D.K. Holdsworth and G. Heers 1971. Further 
caves of Kitava, Trobriand Islands, Papua. Helictite 9(3): 61-70.

Ollier, C.D. and C.F. Pain 1978a. Caves of Woodlark Island, Papua New Guinea. Helictite 16(2):64-70.

Ollier, C.D. and C.F. Pain 1978b. Some megaliths and cave burials, Woodlark Island (Murua), Papua New Guinea. Archaeology and Physical Anthropology in Oceania 13(1):10-18.

Osborne, D. 1966. The Archaeology of the Palau Islands: An intensive survey. Bernice P. Bishop Bulletin 230. Honolulu: Bishop Museum Press.

Pain, C.F. and C.D. Ollier 1978. Caves and karst on Misima Island, Papua New Guinea. Helictite 16(1):40-49.

Parkinson, R. 1999 [1907] Thirty Years in the South Seas: Land and people, customs and traditions in the Bismarck Archipelago and on the German Solomon Islands. Bathurst: Crawford House Press.

Riesenfeld, A. 1950. The Megalithic Culture of Melanesia. Leiden: E.J. Brill.

Rieth, T.M. and J. Liston 2001. Archaeology Data Recovery at Ngermereus Ridge, Ngesaol, Koror, Republic of Palau. Honolulu: IARII.

Röder, J. 1959. Felsbilder und Vorgeschichte des MacCluerGolfes, West-Neuginea. Ergebnisse der FrobeniusExpedition 1937-38 in die Molukken und nach Holländisch Neu-Guinea, Vol. 4. Darmstadt: L.C. Wittich.

Seligman, C.G. 1910. The Melanesians of British New Guinea. Cambridge: Cambridge University Press.

Seligman, C.G. and W.M. Strong 1906. Anthropogeographical investigations in British New Guinea. The Geographical Journal 27:225-242.

Solheim, W.G. II 1998. The University of Hawaii archaeological programme in Eastern Indonesia. In M.J. Klokke and T. de Bruijn (eds) Southeast Asian Archaeology 1996, pp. 61-73. Hull: Centre for South-East Asian Studies.

Specht, J. 1973. Trade and Culture History across the Vitiaz Strait. TACHAUS/2: the 1973 field season. Manuscript report.

Specht, J. and H. Holzknecht 1971. Some archaeological sites in the Upper Markham Valley, Morobe District. Records of the P.N.G. Museum 1(2):52-73.

Stone, O.C. 1880. A Few Months in New Guinea. London.

Suas, J.B. 1917/18. Talu Tuei, les hommes d'autrefois, ou les premiers Hébridais. Anthropos 12-13:201-205.
Terrell, J. 1976. Perspectives on the Prehistory of Bougainville Island, Papua New Guinea: A study in the human biogeography of the Southwestern Pacific. Unpublished $\mathrm{PhD}$ thesis, Harvard University.

Terrell, J. 1986. Prehistory in the Pacific Islands. Cambridge: Cambridge University Press.

Thurnwald, R. 1934. Stone monuments in Buin. Oceania $5(2): 214-217$.

Tindale, N.B. and H.K. Bartlett 1937. Notes on some clay pots from Panaeati Island, South-East of New Guinea. Transactions of the Royal Society of South Australia 61:159-162.

Thompson, L.M. 1932. Archaeology of the Marianas Islands. Bernice P. Bishop Museum Bulletin 100. Honolulu: Bishop Museum Press.

Valentin, F. 2003. Human skeletons recovered in the site of Lapita at Koné (New Caledonia): mortuary and biological features. In C. Sand (ed.) Pacific Archaeology: Assessments and prospects, pp. 285-293. Les Cahiers de l'Archéologie in Nouvelle-Calédonie 15.

Valentin, F. and C. Sand 2000. Archéologie des Morts. Etudes anthropologiques de squelettes préhistoriques de NouvelleCalédonie. Les Cahiers de l'Archéologie en NouvelleCalédonie 11.

Valentin, F. and C. Sand 2001. Inhumations préhistoriques en Nouvelle-Calédonie. Journal de la Société des Océanistes 113(2):135-149.

de Vera, M. and M.W. Young 1980. Secondary burial on Goodenough Island, Papua: some archaeological and ethnographic observations. Occasional Papers in Anthropology, Anthropology Museum, University of Queensland 10:229-248.

Welch, D.J. 2001. Early upland expansion of Palauan settlement. In C.M. Stevenson, G. Lee and F.J. Morin (eds), Pacific 2000: Proceedings of the Fifth International Conference on Easter Island and the Pacific pp. 179-184. Los Osos: Easter Island Foundation.

Williams, F.E. 1931. Papuan Petrographs. Journal of the Royal Anthropological Institute 61:121-155.

Winter, O. 2003. Was there a Kula Ring before the Kula Ring? In A. Karlstrom and A. Kallen (eds), Fishbones and Glittering Emblems: Southeast Asian Archaeology 2002, pp. 119-134. Stockholm: Museum of Far Eastern Antiquities. 